\title{
Leverage, Kepemilikan Manajerial, Kinerja Lingkungan dan Nilai Perusahaan: Studi Empiris pada Perusahaan Manufaktur di Indonesia
}

\author{
Ida Ayu Widhi Rismayanti ${ }^{1}$ \\ Fakultas Ekonomi dan Bisnis \\ Universitas Udayana, Indonesia
}

\author{
I Gusti Ayu Made Asri Dwija Putri² \\ Fakultas Ekonomi dan Bisnis \\ Universitas Udayana, Indonesia
}

\section{Herkulanus Bambang Suprasto $^{3}$ Fakultas Ekonomi dan Bisnis Universitas Udayana, Indonesia \\ Surel : iawidhi.1215@gmail.com}

\section{ABSTRAK}

Nilai perusahaan yang baik tidak hanya digambarkan dengan tingkat pencapaian laba yang tinggi. Adanya penggunaan hutang, sebagian saham yang dimiliki oleh manajerial serta kinerja perusahaan terhadap lingkungannya memiliki kecenderungan untuk meningkatkan nilai perusahaan. Penelitian ini bertujuan untuk menguji secara empiris pengaruh leverage, kepemilikan manajerial dan kinerja lingkungan terhadap nilai perusahaan. Penelitian ini menggunakan perusahaan manufaktur peserta PROPER yang terdaftar di Bursa Efek Indonesia pada periode 2017-2019 sebagai populasi penelitian. Metode penentuan sampel menggunakan purposive sampling. Teknik analisis yang digunakan adalah analisis regresi berganda. Hasil penelitian ini menunjukkan bahwa leverage, kepemilikan manajerial dan kinerja lingkungan mampu meningkatkan nilai perusahaan.

Kata Kunci: Leverage; Kepemilikan Manajerial; Kinerja Lingkungan; Nilai Perusahaan.

Leverage, Managerial Ownership, Environmental Performance and Firm Value: An Empirical Study on Manufacturing Companies in Indonesia

\section{ABSTRACT}

A good company value is more than just a high level of profit achievement. The use of debt, some of the shares owned by management, and the company's performance in relation to its environment all have the potential to increase firm value. The purpose of this study is to empirically test the effect of leverage, managerial ownership, and environmental performance on firm value. The research population for this study is PROPER participating manufacturing companies that are listed on the Indonesia Stock Exchange between 2017 and 2019. Purposive sampling is a method of determining the sample. Multiple regression analysis was used as the analysis technique. According to the findings of this study, leverage, managerial ownership, and environmental performance can all increase firm value.

Keywords: Leverage; Managerial Ownership; Environmental Performance; Firm Value.

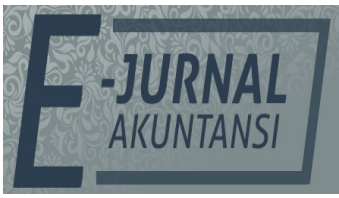

e-ISSN 2302-8556

Vol. 31 No. 7

Denpasar, Juli 2021

Hal. 1667-1679

DOI:

10.24843/EJA.2021.v31.i07.p05

PENGUTIPAN:

Rismayanti, I.A.W., Putri, I

G.A.M.A.D., \& Suprasto, H.B.

(2021). Leverage, Kepemilikan

Manajerial, Kinerja

Lingkungan dan Nilai

Perusahaan: Studi Empiris pada Perusahaan Manufaktur

di Indonesia. E-Jurnal

Akuntansi, 31(7), 1667-1679

RIWAYAT ARTIKEL:

Artikel Masuk:

3 Mei 2021

Artikel Diterima:

4 Juni 2021

Artikel dapat diakses : https://ojs.unud.ac.id/index.php/Akuntansi/index 


\section{PENDAHULUAN}

Perusahaan sebagai salah satu entitas ekonomi umumnya memiliki tujuan jangka pendek maupun jangka panjang. Tujuan jangka pendek perusahaan adalah untuk memperoleh laba secara maksimal, sedangkan tujuan jangka panjangnya adalah untuk meningkatkan nilai perusahaan. Beberapa hal yang menjadi tujuan didirikannya sebuah perusahaan yaitu tujuan yang pertama adalah untuk mencapai keuntungan atau laba yang maksimal, tujuan yang kedua adalah ingin memakmurkan pemilik perusahaan atau pemilik saham, dan tujuan yang ketiga adalah untuk memaksimalkan nilai perusahaan yang tercermin pada harga sahamnya (Husnan \& Pudjiastuti, 2015).

Menurut Inastri \& Mimba (2017) nilai perusahaan adalah tujuan utama dari perusahaan, dengan nilai perusahaan yang semakin baik akan meningkatkan kemakmuran bagi para pemegang saham. Semakin tinggi harga saham, maka semakin tinggi pula nilai perusahaan. Nilai perusahaan yang tinggi menjadi keinginan para pemilik perusahaan, sebab dengan nilai yang tinggi menunjukan kemakmuran pemegang saham yang tinggi. Selain itu investor juga lebih cenderung menanamkan sahamnya pada perusahaan yang memiliki kinerja baik dalam meningkatkan nilai perusahaan.

Nilai perusahaan sangat penting bagi perusahaan, karena maksimalisasi nilai perusahaan berarti memaksimalkan kemakmuran pemegang saham yang merupakan tujuan utama perusahaan (Wirawati et al., 2020). Menurut CNBC Indonesia, 27 februari 2020 menyatakan kapitalisasi sektor manufaktur raib sebesar Rp 309 triliun, dimana salah satu sektor dari 10 sektoral di BEI yang mengalami koreksi dalam hari ini adalah sektor manufaktur yang terkoreksi $2,16 \%$. Sektor manufaktur ini salah satu yang mengalami koreksi selama tahun berjalan atau year to date, yaitu $13,57 \%$ hingga perdagangan Rabu $(26 / 2 / 2020)$. Nilai kapitalisasi saham sektor manufaktur tercatat tergerus Rp 309,13 triliun dari Rp 2.317,14 triliun di akhir 2019 menjadi Rp 2.008,01 triliun pada perdagangan rabu kemarin. Nilai kapitalisasasi mencerminkan nilai perusahaan dan secara nominal, penurunan nilai kapitalisasi tersebut merupakan yang terbesar dari 10 sektor. Berdasarkan fenomena turunnya nilai perusahaan diatas, terdapat banyak faktor yang dapat mempengaruhi turunnya nilai perusahaan yaitu leverage, kepemilikan manajerial dan kinerja lingkungan.

Nilai perusahaan yang baik dapat digambarkan dengan pengelolaan hutang yang baik dalam operasional perusahaan. Bagi pihak eksternal seperti kreditur, laporan keuangan dapat digunakan sebagai bahan pertimbangan dalam pemberian kredit atau pinjaman modal. Solvabilitas atau leverage digunakan untuk melihat sejauh mana aset perusahaan dibiayai oleh hutang (Wiagustini, 2014). Leverage merupakan pengukur besarnya aktiva yang dibiayai dengan utang (Nugrahitha \& Suprasto, 2018). Utang yang digunakan untuk membiayai aktiva berasal dari kreditor, bukan dari pemegang saham ataupun investor. (Bailey, 1989) menyatakan seberapa jauh perusahaan menggunakan utang (financial leverage) akan memiliki implikasi penting, salah satunya adalah dengan memperoleh dana melalui utang, para pemegang saham dapat mempertahankan kendali mereka atas perusahaan tersebut dengan sekaligus membatasi investasi yang mereka berikan. Perusahaan dengan rasio leverage yang tinggi mengakibatkan pengawasan yang tinggi dilakukan oleh kreditor terhadap aktivitas perusahaan. 
Penelitian dari Prasetyorini (2013) menyatakan leverage tidak berpengaruh terhadap nilai perusahaan. Sari \& Abundanti (2014) menyatakan leverage berpengaruh negatif terhadap nilai perusahaan, sedangkan penelitian yang dilakukan oleh Sutama \& Lisa (2018) menyatakan bahwa leverage berpengaruh positif terhadap nilai perusahaan. Meningkatnya nilai leverage dapat meningkatkan nilai perusahaan (Budiharjo, 2020).

Kepemilikan manajerial juga dapat mempengaruhi nilai perusahaan. Sudana (2011) berpendapat bahwa kepemilikan manajerial merupakan pemisah antara pemilik dan manajer perusahaan. Kepemilikan manajerial adalah kepemilikan saham sekaligus sebagai pihak manajemen perusahaan. Kepemilikan saham manajerial dapat digunakan untuk mensejalankan antara kepentingan pemegang saham dengan manajer. Sebagai pemilik perusahaan sekaligus sebagai manajer pada perusahaan tersebut, maka manajer akan ikut merasakan langsung manfaat dari kebijakan yang diambil untuk perusahaan dan manajer juga akan ikut menanggung risiko apabila ada kerugian yang timbul sebagai konsekuensi dari pengambilan keputusan yang salah, tetapi sebaliknya manajer juga akan dapat ikut merasakan keuntungan perusahaan apabila kebijakan yang diambil berpengaruh positif terhadap perusahaan. Dengan kepemilikan manajerial, diharapkan manajer dapat memperbaiki kinerjanya dengan menghilangkan kepentingan pribadi sesuai dengan keinginan para pemegang saham sehingga manajer akan termotivasi sehingga dapat meningkatkan nilai perusahaan. Penelitian El-Habashy (2019); Putranto \& Kurniawan (2018) menyatakan bahwa kepemilikan manajerial berpengaruh positif terhadap nilai perusahaan. Penelitian Pınar \& Guluzar (2010) menyatakan bahwa kepemilikan manajerial berpengaruh negatif terhadap nilai perusahaan.

Faktor lain yang dapat meningkatkan suatu nilai perusahaan yaitu dengan baiknya kinerja lingkungan suatu perusahaan. Bentuk pertanggungjawaban perusahaan yang semakin baik terhadap kelestarian lingkungan hidup maka akan membuat reputasi perusahaan akan menjadi baik. Hal ini terjadi karena perusahaan telah mampu memenuhi kontrak sosial atau legitimasi terhadap masyarakat sehingga keberadaannya akan direspon positif oleh masyarakat atau investor (Hariati \& Rihatiningtyas, 2015). Perusahaan yang memiliki reputasi baik nantinya akan membuat ketertarikan investor, dimana biasanya investor akan memilih perusahaan yang mempunyai reputasi baik untuk di tanamkan dananya. Perusahaan yang tidak memperhatikan seluruh faktor yang mengelilinginya, maka eksistensi perusahaan itu bisa berakhir dan kegiatan operasi perusahaan tersebut bisa terhenti (Sueb, 2001). Maka seharusnya perusahaan memikirkan cara agar bisa mencapai tujuannya memperoleh laba yang tinggi dengan memperhitungkan dampak sosial maupun lingkungan sekitar perusahaan.

Di Indonesia, penilaian kinerja lingkungan dapat dilihat pada peringkat PROPER (Program Penilaian Peringkat Kinerja Perusahaan) yang merupakan program penilaian yang dilaksanakan oleh Kementrian Lingkungan Hidup pada perusahaan-perusahaan yang secara langsung terlibat dalam penggunaan sumber daya alam di sekitarnya. Berdasarkan surat keputusan Kementrian Lingkungan Hidup dan Kehutanan, peningkatan jumlah peserta PROPER diikuti dengan meningkatnya jumlah nilai merah dari perusahaan yang berarti kinerja lingkungan perusahaan tersebut masih buruk. Pengungkapan yang berkaitan 
dengan informasi lingkungan memberikan beberapa keuntungan kepada berbagai pihak, diantaranya ketertarikan pemegang saham dan pemangku kepentingan. Perusahaan yang memberikan informasi tentang lingkungan dalam laporan keuangannya akan mendapatkan pandangan atau respon yang baik dari masyarakat serta berpengaruh terhadap nilai perusahaan. Hal ini sejalan dengan penelitian yang di lakukan oleh Auliya \& Margasari (2018) yang menyatakan adanya pengaruh positif antara kinerja lingkungan terhadap nilai perusahaan, namun penelitian tersebut bertolak belakang dengan penelitian yang dilakukan oleh Tjahjono (2013) yang menyatakan tidak ada pengaruh kinerja lingkungan terhadap nilai perusahaan.

Perusahaan manufaktur peserta PROPER dipilih sebagai objek penelitian karena perusahaan manufaktur yang terdaftar di Bursa Efek Indonesia terdiri dari berbagai sub sektor indrustri dan merupakan perusahaan yang secara langsung terlibat dalam penggunaan sumber daya alam di sekitarnya dan perusahaan manufaktur lebih mudah terpengaruh oleh kondisi ekonomi dan memiliki tingkat sensitifitas yang tinggi terhadap setiap kejadian baik internal maupun ekternal perusahaan. Penelitian ini menggunakan periode dari tahun 2017-2019 dan penelitian ini dilakukan untuk mengetahui apakah hasil yang akan diperoleh nantinya dapat mendekati atau berbeda dengan penelitian-penelitian sebelumnya. Penelitian ini memiliki keterbaharuan pada tahun dan sektor yang berbeda dengan penelitian sebelumnya, dimana penelitian ini menggunakan tahun 20172019 pada sektor manufaktur sedangkan penelitian sebelumnya yang dilakukan oleh Sari \& Abundanti (2014) dilakukan tahun 2009-2011 pada sektor perusahaan food and beverage dan Putranto \& Kurniawan (2018) dilakukan tahun 2012-2015 pada sektor perusahaan food and beverage.

Pengaruh leverage terhadap nilai perusahaan didasarkan pada trade off theory, karena trade off theory adalah teori mengenai capital structure dalam memperoleh rasio leverage yang optimal dengan mempertimbangkan antara manfaat dan biaya dari penggunaan leverage (Adair \& Adaskou, 2015). Trade off theory menyatakan bahwa capital structure optimal akan tercapai bila manfaat nilai tambah dari penggunaan leverage yang berupa penghematan pajak seimbang dengan biaya yang dikeluarkan. Nilai perusahaan akan mencapai nilai maksimal apabila sebagian modal dibiayai oleh leverage namun jika perusahaan memiliki leverage yang banyak lalu perusahaan tidak mampu membayar kewajiban maka perusahaan akan menghadapi biaya financial distress yang dapat menyebabkan kebangkrutan. Leverage diproksikan dengan rasio Debt to Equity Ratio (DER).

Debt to Equity Ratio (DER) dapat memberikan gambaran mengenai struktur modal yang dimiliki oleh perusahaan sehingga dapat dilihat tingkat risiko yang tak terbayarkan suatu hutang (Deitiana, 2009). DER juga menunjukkan tingkat hutang perusahaan, perusahaan dengan hutang besar mempunyai biaya hutang yang besar pula. Hal tersebut menjadi beban bagi perusahaan yang dapat menurunkan tingkat kepercayaan investor. Namun Keuntungan perusahaan menggunakan hutang yaitu bunga yang dibayarkan dapat dipotong untuk tujuan pajak, sehingga menurunkan biaya efektif dari hutang. Hutang juga digunakan sebagai penunjang sebuah perusahaan untuk melakukan kegiatan operasional agar tujuan perusahaan yang telah ditetapkan dapat tercapai. Keputusan struktur modal yang efektif dapat merendahkan biaya modal yang dikeluarkan oleh 
perusahaan. Uraian tersebut didukung oleh penelitian Setiawanta \& Hakim (2019) dan Sutama \& Lisa (2018) yang mengatakan bahwa DER berpengaruh positif terhadap Nilai Perusahaan.

$\mathrm{H}_{1}$ : Leverage berpengaruh positif terhadap nilai perusahaan.

Pengaruh kepemilikikan manajerial terhadap nilai perusahaan didasarkan pada teori keagenan (agency theory), karena teori keagenan mendeskripsikan hubungan antara pemegang saham (shareholders) sebagai principal dan manajemen sebagai agen. Seperti pemilik perusahaan dan manajemen perusahaan, dimana agen menutup kontrak untuk melakukan tugas-tugas tertentu bagi principal dan principal menutup kontrak untuk memberi imbalan kepada agen. Kepemilikan manajerial merupakan proporsi pemegang saham dari pihak manajemen yang secara aktif ikut dalam pengambilan keputusan perusahaan. Kepemilikan manajerial ini timbul sebagai upaya untuk meminimumkan konflik kepentingan antara principal dan agen.

Semakin besar proporsi kepemilikan saham manajemen pada perusahaan, maka manajemen cenderung berusaha lebih giat untuk kepentingan pemegang saham yang tidak lain adalah dirinya sendiri (Ariyanto et al., 2021) dan (Mardianto \& Tiono, 2019). Kepemilikan saham manajemen akan membantu penyatuan kepentingan manajer dan pemegang saham, sehingga manajer ikut merasakan secara langsung manfaat dari keputusan yang diambil dan ikut pula menanggung kerugian sebagai konsekuensi dari pengambilan keputusannya. Manajer yang sekaligus pemegang saham akan meningkatkan nilai perusahaan, sehingga nilai kekayaannya sebagai pemegang saham akan meningkat juga. Hal tersebut didasarkan pada logika, bahwa adannya peningkatan proporsi saham yang dimiliki oleh manajer akan menurunkan kecenderungan manajer untuk melakukan tindakan yang menyimpang (Suparmini et al., 2020). Maka akan mempersatukan kepentingan antara manajer dan pemegang saham yang nantinnya akan berdampak pada peningkatan nilai perusahaan. Uraian tersebut didukung oleh penelitian Julianti (2015) menyatakan bahwa kepemilikan manajerial berpengaruh positif terhadap nilai perusahaan dan (Kusumawati \& Setiawan, 2019) menyatakan bahwa kepemilikan manajerial berpengaruh terhadap nilai perusahaan. Berdasarkan uraian di atas maka dapat dirumuskan hipotesis yaitu sebagai berikut.

$\mathrm{H}_{2}$ : Kepemilikan manajerial berpengaruh positif terhadap nilai perusahaan.

Pengaruh kinerja lingkungan terhadap nilai perusahaan didasarkan pada teori legitimasi, karena teori legistimasi menyatakan perusahaan perlu untuk memastikan bahwa operasi yang dijalankannya sah dimata masyarakat dan lingkungan sekitarnya, sehingga operasi perusahaan dapat terus berkelanjutan. Entitas bisnis harus memiliki tujuan organisasi yang searah dengan lingkungan setempat, sehingga keberadaan perusahaan bisa terus berlanjut dan nilai perusahaan meningkat.

Nilai perusahaan merupakan persepsi investor terhadap tingkat pencapaian perusahaan yang terkait dengan harga saham dan dapat memberikan kemakmuran bagi pemegang saham secara maksimum apabila harga saham meningkat. Faktor lain yang dapat meningkatkan suatu nilai perusahaan yaitu dengan baiknya kinerja lingkungan suatu perusahaan. Bentuk pertanggungjawaban perusahaan yang semakin baik terhadap kelestarian 
lingkungan hidup maka akan membuat reputasi perusahaan akan menjadi baik. Aktivitas pengelolaan lingkungan yang dilakukan secara maksimal dapat menimbulkan respon positif bagi investor yang ditunjukkan melalui peningkatan nilai saham perusahaan. Aktivitas pelestarian lingkungan akan memberikan nilai plus bagi organisasi bisnis sehingga pemegang saham akan tertarik untuk menanamkan modalnya kepada perusahaan yang memiliki kinerja lingkungan yang baik. Uraian tersebut didukung oleh penelitian Auliya \& Margasari (2018), Mardiana \& Wuryani (2019), dan Saputra \& Mahyuni (2018) bahwa terdapat pengaruh positif kinerja lingkungan terhadap nilai perusahaan.

$\mathrm{H}_{3}$ : Kinerja lingkungan berpengaruh positif terhadap nilai perusahaan.

\section{METODE PENELITIAN}

Populasi dalam penelitian ini adalah perusahaan Manufaktur yang terdaftar di Bursa Efek Indonesia periode 2017-2019. Sampel dipilih menggunakan teknik purposive sampling dengan kriteria 1) Perusahaan Manufaktur peserta PROPER yang terdaftar di Bursa Efek Indonesia periode tahun 2017-2019; 2) Perusahaan Manufaktur yang mempublikasikan annual report periode tahun 2017-2019; 3) Perusahaan yang sebagian sahamnya dimiliki oleh manajer perusahaan periode tahun 2017-2019. Sehingga didapat 39 perusahaan manufaktur sebagai sampel penelitian.

Penelitian ini menggunakan jenis data kuantitatif berupa data sekunder yang terdiri dari laporan keuangan, laporan tahunan dan hasil penilaian PROPER. Berdasarkan hipotesis yang diajukan, diidentifikasi ada dua jenis variabel dalam penelitian ini yaitu leverage yang diproksikan dengan Debt to equity ratio, kepemilikan manajerial yang di proksikan dengan persentase kepemilikan manajerial perusahaan dan kinerja lingkungan yang diproksikan dengan penilaian PROPER sebagai variabel independen. Nilai perusahaan yang diproksikan dengan nilai Tobin,s Q sebagai variabel dependen. Pengolahan data dilakukan dengan analisis regresi berganda dengan menggunakan software SPSS 22.0 for Windows, dan sebelumnya dilakukan uji asumsi klasik. Hasil analisis selanjutnya diinterpretasikan sehingga dapat menjawab permasalahan yang ada dan diakhiri dengan membuat simpulan atas hasil yang diperoleh, serta memberi saran-saran untuk penelitian selanjutnya yang akan mengangkat topik yang sama. Teknik analisis yang digunakan yaitu analisis regresi linier berganda dengan persamaan regresi sebagai berikut.

$Y=\alpha+\beta_{1} X_{1}+\beta_{2} X_{2}+\beta_{3} X_{3}+\beta_{4} X_{4}+\varepsilon$

\section{HASIL DAN PEMBAHASAN}

Analisis statistik deskriptif adalah teknik deskriptif yang memberikan informasi tentang data yang dimiliki dan tidak bermaksud menguji hipotesis, dan berfungsi untuk menganalisis data dengan mendeskripsikan data yang telah dikumpulkan tanpa bermaksud membuat kesimpulan yang berlaku untuk umum atau generalisasi (Sugiyono, 2017). Dalam analisis statistik deskriptif, pengukuran yang digunakan meliputi jumlah sampel, nilai minimum, nilai maksimum, nilai ratarata (mean), dan standar deviasi (Ghozali, 2016). Berikut ini disajikan hasil statistik deskriptif pengujian pengaruh leverage, kepemilikan manajerial dan kinerja lingkungan pada nilai perusahaan pada Tabel 1. 
Tabel 1. Statistik Deskriptif

\begin{tabular}{lcrrrr}
\hline & $\mathrm{N}$ & Minimum & Maximum & Mean & Std. Deviation \\
\hline DER & 39 & 1,200 & 333,890 & 68,892 & 81,662 \\
KM & 39 & 0,010 & 36,020 & 9,453 & 11,684 \\
PROPER & 39 & 2,000 & 4,000 & 3,000 & 0,324 \\
TobinsQ & 39 & 0,120 & 6,910 & 1,265 & 1,626 \\
Valid N (listwise) & 39 & & & & \\
\hline
\end{tabular}

Sumber: Data Penelitian, 2020

Berdasarkan Tabel 1, maka dapat dijelaskan statistik deskriptif dari masing-masing variabel penelitian yakni, Variabel leverage $\left(\mathrm{X}_{1}\right)$, memiliki nilai minimum sebesar 1,20 dan nilai maksimum sebesar 333,89. Nilai mean variabel leverage sebesar 68,8923 , hal ini berarti rata-rata hutang atas modal yang dimiliki perusahaan manufaktur sebesar 68,8923. Nilai standar deviasi variabel leverage sebesar 81,66222. Variabel kepemilikan manajerial memiliki nilai standar deviasi yang lebih besar dari nilai mean, artinya variabel leverage menunjukkan data yang bervariasi. Variabel kepemilikan manajerial $\left(\mathrm{X}_{2}\right)$, memiliki nilai minimum sebesar 0,01 dan nilai maksimum sebesar 36,02. Nilai mean variabel kepemilikan manajerial sebesar 9,4537, hal ini berarti rata-rata kepemilikan saham oleh manajerial perusahaan manufaktur sebesar 9,4537. Nilai standar deviasi variabel kepemilikan manajerial sebesar 11,68477. Variabel kepemilikan manajerial memiliki nilai standar deviasi yang lebih besar dari nilai mean, artinya variabel kepemilikan manajerial menunjukkan data yang bervariasi. Variabel kinerja lingkungan $\left(\mathrm{X}_{3}\right)$, memiliki nilai minimum sebesar 2,00 dan nilai maksimum sebesar 4,00. Nilai mean variabel kinerja lingkungan sebesar 3,00, hal ini berarti rata-rata kinerja lingkungan perusahaan nanufaktur sebesar 3,00. Nilai standar deviasi variabel kinerja lingkungan sebesar 0,32444. Variabel kinerja lingkungan memiliki nilai standar deviasi yang lebih kecil dari nilai mean, artinya variabel kinerja keuangan memiliki fluktuasi yang kecil yaitu sebesar 0,32444, dan rentangan jarak antara nilai minimum dan nilai maksimum variabel kinerja lingkungan tergolong kecil. Variabel nilai perusahaan $(Y)$, memiliki nilai minimum sebesar 0,12 dan nilai maksimum sebesar 6,91. Nilai mean variabel nilai perusahaan sebesar 1,2656, hal ini berarti rata-rata nilai perusahaan manufaktur sebesar 1,2656. Nilai standar deviasi variabel nilai perusahaan sebesar 1,62617. Variabel kinerja keuangan memiliki nilai standar deviasi yang lebih besar dari nilai mean, artinya variabel nilai perusahaan menunjukkan data yang bervariasi.

Hasil uji normalitas pada persamaan memiliki nilai Kolmogorov Smirnov (KS) sebesar 0,950 dan nilai Asymp. Sig. (2-tailed) sebesar 0,328, hasil ini mengindikasikan bahwa model persamaan regresi berdistribusi normal karena nilai Asymp. Sig. (2-tailed) lebih besar dari nilai level of significant 0,05 (5\%). Jadi dapat disimpulkan bahwa nilai residual pada model regresi yang diuji sudah berdistribusi normal.

Model regresi dikatakan terbebas dari autokorelasi apabila nilai Aymp.Sig (2-tailed) pada uji Run Test memiliki nilai lebih dari 0,05. Hasil uji menunjukkan bahwa besarnya nilai Aymp. Sig. (2-tailed) pada uji Run Test sebesar 0,104 yang lebih dari 0,05, maka dapat disimpulkan bahwa tidak terdapat autokorelasi antar nilai residual. 
Uji multikolinearitas bertujuan untuk menguji apakah pada model regresi ditemukan adanya korelasi antar variabel bebas. Multikolinearitas dapat dilihat dari nilai tolerance atau variance inflation factor (VIF). Jika nilai tolerance lebih dari $10 \%$ atau VIF kurang dari 10, maka dapat dikatakan model telah bebas dari masalah multikolinearitas (Utama, 2016). Hasil uji multikolinearitas disajikan pada Tabel 2.

Tabel 2. Hasil Uji Multikolinearitas

\begin{tabular}{llll}
\hline Variabel & Tolerance & VIF & Keterangan \\
\hline Leverage & 0,853 & 1,172 & Bebas Multikolinieritas \\
Kepemilikan manajerial & 0,896 & 1,117 & Bebas Multikolinieritas \\
Kinerja lingkungan & 0,948 & 1,055 & Bebas Multikolinieritas \\
\hline
\end{tabular}

Sumber: Data Penelitian, 2020

Berdasarkan Tabel 2, dapat dilihat bahwa nilai VIF dan Tolerance, dimana diperlihatkan bahwa tidak terdapat nilai Tolerance yang lebih dari $10 \%(0,01)$ ataupun nilai VIF yang tidak lebih dari 10. Oleh karena itu berdasarkan nilai Tolerance dan VIF pada model analisis tersebut tidak ditemukan adanya gejala multikolinearitas.

Uji heteroskedastisitas bertujuan untuk menguji apakah dalam model regresi terjadi ketidaksamaan varians dari residual satu pengamatan ke pengamatan lainnya. Model regresi yang baik adalah yang tidak mengandung varians yang homogen. Uji heteroskedastisitas dalam penelitian ini dilakukan dengan uji Glejser (Utama, 2016). Uji Glejser dilakukan dengan cara meregresi nilai absolute residual dari model yang diestimasi terhadap variabel bebas. Jika nilai signifikannya lebih dari 0,05 maka tidak terjadi gejala heteroskedastositas.

Hasil heteroskedastisitas menunjukkan menunjukkan bahwa nilai signifikansi leverage $\left(\mathrm{X}_{1}\right)$ sebesar 0,071, Kepemilikan manajerial $\left(\mathrm{X}_{2}\right)$ sebesar 0,917 dan kinerja lingkungan $\left(X_{3}\right)$ sebesar 0,762 . Hasil uji tersebut memiliki nilai yang lebih besar dari $a=0,05$ yang berarti bahwa tidak terdapat pengaruh antara variabel bebas terhadap absolute residual. Hasil tersebut menunjukkan bahwa model yang digunakan tidak mengandung gejala heteroskedastisistas.

Analisis regresi linier berganda ini digunakan untuk menganalisis pengaruh leverage $\left(X_{1}\right)$, Kepemilikan manajerial $\left(X_{2}\right)$ dan kinerja lingkungan $\left(X_{3}\right)$ terhadap Nilai perusahaan $(\mathrm{Y})$. Analisis regresi linear berganda diolah dengan bantuan software SPSS for Windows 22.0 dengan hasil yang dapat dilihat pada Tabel 3.

Tabel 3. Hasil Analisis Regresi Linear Berganda

\begin{tabular}{|c|c|c|c|c|c|}
\hline \multirow[t]{2}{*}{ Model } & \multicolumn{2}{|c|}{$\begin{array}{c}\text { Unstandardized } \\
\text { Coefficients }\end{array}$} & \multirow{2}{*}{$\begin{array}{c}\begin{array}{c}\text { Standardized } \\
\text { Coefficients }\end{array} \\
\text { Beta }\end{array}$} & \multirow[t]{2}{*}{$\mathrm{t}$} & \multirow[t]{2}{*}{ Sig. } \\
\hline & $\mathrm{B}$ & Std. Error & & & \\
\hline 1 (Constant) & 0,065 & 0,122 & & 0,536 & 0,595 \\
\hline DER & 0,400 & 0,123 & 0,432 & 3,265 & 0,002 \\
\hline KM & 0,501 & 0,129 & 0,501 & 3,878 & 0,000 \\
\hline PROPER & 0,311 & 0,116 & 0,336 & 2,671 & 0,011 \\
\hline Adjusted R Square & 0,431 & & & & \\
\hline Sig. F & 0,000 & & & & \\
\hline
\end{tabular}

Sumber: Data Penelitian, 2020

Dari hasil analisis regresi linear berganda pada Tabel 3, maka dapat dibuat persamaan sebagai berikut. 


$$
Y=0,065+0,400 X_{1}+0,501 X_{2}+0,311 X_{3}+\varepsilon
$$

Nilai koefisien regresi variabel bebas dalam penelitian ini memiliki nilai signifikansi uji t kurang dari 0,05 . Hal ini menunjukkan bahwa seluruh variabel penelitian ini yang terdiri dari leverage $\left(X_{1}\right)$, Kepemilikan manajerial $\left(X_{2}\right)$ dan kinerja lingkungan $\left(X_{3}\right)$ memiliki pengaruh signifikan terhadap variabel Nilai perusahaan.

Hasil penelitian menunjukkan bahwa leverage memiliki pengaruh positif terhadap nilai perusahaan. Arah positif tersebut memiliki arti bahwa semakin tinggi leverage maka semakin tinggi pula nilai perusahaan yang diperoleh. Modal kerja menjadi penunjang utama sebuah perusahaan untuk melakukan kegiatan operasional agar tujuan perusahaan yang telah ditetapkan dapat tercapai. Keputusan struktur modal yang efektif dapat merendahkan biaya modal yang dikeluarkan oleh perusahaan. Penggunaan leverage mampu meningkatkan nilai perusahaan karena perusahaan mampu meningkatkan tingkat produksi untuk memperoleh laba yang lebih besar akibat penggunaan hutang. Keuntungan perusahaan menggunakan hutang yaitu bunga yang dibayarkan dapat dipotong untuk tujuan pajak, sehingga menurunkan biaya efektif dari hutang. Rasio ini juga memberikan kesempatan bagi perusahaan untuk berekspansi sehingga dapat meningkatkan jumlah laba yang dihasilkan dan pada akhirnya dapat memberikan pengaruh positif terhadap Nilai Perusahaan. Hasil penelitian ini juga sejalan dengan penelitian Setiawanta \& Hakim (2019) dan Sutama \& Lisa (2018) yang mengatakan bahwa DER berpengaruh signifikan terhadap Nilai Perusahaan. Budiharjo (2020) juga memperoleh hasil penelitian bahwa terdapat pengaruh positif leverage terhadap nilai perusahaan. Hasil penelitian ini juga mendukung teori trade off yang menyatakan bahwa capital structure optimal akan tercapai bila manfaat nilai tambah dari penggunaan leverage yang berupa penghematan pajak seimbang dengan biaya yang dikeluarkan. Nilai perusahaan akan mencapai nilai maksimal apabila sebagian modal dibiayai oleh leverage.

Hasil penelitian ini menunjukkan bahwa kepemilikan manajerial berpengaruh positif terhadap nilai perusahaan. Dengan adanya kepemilikan manajemen dalam sebuah perusahaan, akan menimbulkan dugaan yang menarik bahwa nilai perusahaan meningkat sebagai akibat kepemilikan manajemen yang meningkat. Kepemilikan oleh manajemen yang besar akan efektif dalam memonitoring aktivitas perusahaan. Semakin besar proporsi kepemilikan saham manajemen pada perusahaan, maka manajemen cenderung berusaha lebih giat untuk kepentingan pemegang saham yang tidak lain adalah dirinya sendiri. Kepemilikan saham manajemen akan membantu penyatuan kepentingan manajer dan pemegang saham, sehingga manajer ikut merasakan secara langsung manfaat dari keputusan yang diambil dan ikut pula menanggung kerugian sebagai konsekuensi dari pengambilan keputusannya. Hasil penelitian ini sejalan dengan hasil penelitian dari Julianti (2015) menyatakan bahwa kepemilikan manajerial berpengaruh positif terhadap nilai perusahaan. Penelitian Kusumawati \& Setiawan (2019) menyatakan bahwa kepemilikan manajerial berpengaruh terhadap nilai perusahaan. Semakin besar kepemilikan manajerial maka dapat meningkatkan nilai perusahaan. Karena semakin besar proporsi kepemilikan saham manajemen pada perusahaan, maka manajemen cenderung berusaha lebih giat untuk kepentingan pemegang saham yang tidak lain adalah dirinya sendiri. 


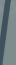

Hasil penelitian ini juga mendukung teori keagenan yang mendeskripsikan hubungan antara pemegang saham (shareholders) sebagai principal dan manajemen sebagai agen. Seperti pemilik perusahaan dan manajemen perusahaan, dimana agen menutup kontrak untuk melakukan tugastugas tertentu bagi principal dan principal menutup kontrak untuk memberi imbalan kepada agen. Kepemilikan manajerial ini timbul sebagai upaya untuk meminimumkan konflik kepentingan antara principal dan agen (Jensen \& Meckling, 1976). Dengan adannya peningkatan proporsi saham milik manajemen akan menurunkan kecenderungan manajer melakukan tindakan menyimpang. Maka akan mempersatukan kepentingan antara manajer dan pemegang saham, Sehingga akan berdampak pula pada peningkatan nilai perusahaan.

Berdasarkan hasil uji penelitian ini menunjukkan bahwa kinerja lingkungan berpengaruh terhadap nilai perusahaan. Kinerja lingkungan menjadi upaya perusahaan dalam membentuk aktivitas pengelolaan lingkungan yang baik. Aktivitas pengelolaan lingkungan yang dilakukan secara maksimal dapat menimbulkan respon positif bagi investor yang ditunjukkan melalui peningkatan nilai saham perusahaan. Hasil ini sesuai dengan penelitian Auliya \& Margasari (2018), Mardiana \& Wuryani (2019), dan Saputra \& Mahyuni (2018) bahwa terdapat pengaruh positif kinerja lingkungan terhadap nilai perusahaan. Hasil penelitian ini juga mendukung teori legitimasi, yang menyatakan perusahaan akan berupaya untuk memenuhi tanggungjawabnya kepada masyarakat melalui kegiatan pengelolaan lingkungan dengan harapan mendapatkan legitimasi dari masyarakat dan respon positif dari pihak stakeholder. Aktivitas pelestarian lingkungan akan memberikan nilai plus bagi organisasi bisnis sehingga pemegang saham akan tertarik untuk menanamkan modalnya kepada perusahaan yang memiliki kinerja lingkungan yang baik.

Berdasarkan hasil penelitian yang dilakukan, bahwa leverage, kepemilikan manajerial dan kinerja lingkungan berpengaruh terhadap nilai perusahaan manufaktur yang terdaftar di BEI. Hal ini berarti baik dan buruknya nilai perusahaan dapat dipengaruhi oleh leverage, kepemilikan manajerial dan kinerja lingkungan. Leverage yang berkaitan dengan pembiayaan perusahaan melalui hutang. Hutang dapat membantu perusahaan menambah pendanaan perusahaan ketika modal perusahaan tidak mencukupi. Kepemilikan manajerial merupakan kepemilikan sebagian saham oleh pihak manajemen yang mana mampu mendorong manajemen agar lebih mengutamakan kepentingan pemegang saham yang juga adalah dirinya sendiri. Kinerja lingkungan berkaitan dengan dampak yang ditimbulkan dari operasi perusahaan terhadap lingkungan sekitarnya. Perusahaan perlu untuk memastikan bahwa operasi yang dijalankannya sah dimata masyarakat dan lingkungan sekitarnya. Adanya pengelolaan leverage yang baik, kepemilikan manajerial dan kinerja lingkungan yang baik tentu akan dapat meningkatkan nilai perusahaan.

\section{SIMPULAN}

Berdasarkan hasil pengujian dan pembahasan, maka hasil penelitian dapat disimpulkan sebagai berikut yakni Leverage berpengaruh positif pada nilai perusahaan pada perusahaan manufaktur yang terdaftar di Bursa Efek Indonesia periode 2017-2019. Artinya semakin tinggi nilai leverage maka nilai perusahaan 
akan semakin meningkat. Kepemilikan manajerial berpengaruh positif pada nilai perusahaan pada perusahaan manufaktur yang terdaftar di Bursa Efek Indonesia periode 2017-2019. Artinya semakin besar nilai kepemilikan saham oleh manajerial akan mampu meningkatkan nilai perusahaan. Kinerja lingkungan berpengaruh positif pada nilai perusahaan pada perusahaan manufaktur yang terdaftar di Bursa Efek Indonesia periode 2017-2019. Artinya semakin tinggi nilai kinerja lingkungan maka nilai perusahaan akan semakin meningkat.

Berdasarkan atas simpulan penelitian, maka saran yang dapat disampaikan yakni bagi pihak perusahaan, dalam pengelolaan perusahaan selain mementingkan laba, perusahaan juga harus memperhatikan pengelolaan hutang dan manajemen perusahaan dengan baik serta tetap menjaga lingkungan di sekitar tempat perusahaan beroperasi. Hal ini dapat menjaga keberlangsungan operasional perusahaan dan dapat meningkatkan nilai perusahaan. Bagi pihak investor, sebelum melakukan investasi selain memperhatikan kinerja keuangan perusahaan, sebaiknya penting juga untuk memperhatikan pengelolaan hutang dan manajemen serta kinerja lingkungan perusahaan. Nilai perusahaan tanpa didukung oleh kinerja lingkungan tidak akan menjamin keberlanjutan dan keberadaan suatu perusahaan.

Keterbatasan penelitian ini adalah sampel penelitian ini masih tergolong sedikit karena perusahaan yang mengadakan program kepemilikan saham oleh manajerial masih sedikit. Bagi para peneliti untuk penelitian selanjutnya dapat memperluas periode penelitian serta menggunakan variable lain seperti CGPI. Peneliti juga dapat mengadakan penelitian pada nilai perusahaan di masa pandemi dan meneliti nilai perusahaan sektor lainnya yang berdampak di masa pandemi.

\section{REFERENSI}

Adair, P., \& Adaskou, M. (2015). Trade-off theory vs. Pecking order theory and the determinants of corporate leverage: Evidence from a panel data analysis upon french SMEs (2002-2010). Cogent Economics and Finance, 3(1). https://doi.org/10.1080/23322039.2015.1006477

Ariyanto, D., Jhuniantara, I. M. G., Ratnadi, N. M. D., Putri, I. G. A. M. A. D., \& Dewi, A. A. (2021). Detecting fraudulent financial statements in pharmaceutical companies $\square$ : Fraud pentagon theory perspective. Accounting, 7(7), 1-10. https://doi.org/10.5267/j.ac.2021.5.009

Auliya, M. R., \& Margasari, N. (2018). Pengaruh Kinerja Lingkungan Terhadap Corporate Financial dengan Corporate Social Responsibility sebagai Variabel Intervening. Jurnal Ekonomi Universitas Negeri Yogyakarta, 1(1), 117-142.

Bailey, F. . (1989). Intermediate financial management. The British Accounting Review. https:// doi.org/10.1016/0890-8389(89)90100-5

Budiharjo, R. (2020). Effect of Firm Size and Leverage on Firm Value with Return On Equity as Intervening Variables. International Journal of Economics and Management Studies, 7(4), https://doi.org/10.14445/23939125/ijems-v7i4p119

Deitiana, T. (2009). Faktor-Faktor Yang Mempengaruhi Kebijakan Pembayaran Dividen Kas. Jurnal Bisnis Dan Akuntansi, 11(1), 57-64.

El-Habashy, H. A. (2019). The effects of board and ownership structures on the 
performance of publicly listed companies in Egypt. Academy of Accounting and Financial Studies Journal, 23(1), 1-15.

Ghozali, I. (2016). Aplikasi Analisis Multivariate dengan Program IBM SPSS 23.

Semarang: Badan Penerbit Universitas Diponegoro.

Hariati, I., \& Rihatiningtyas, Y. W. (2015). Pengaruh Tata Kelola Perusahaan Dan Kinerja Lingkungan Terhadap Nilai Perusahaan. Simposium Nasional Akuntansi XVIII, Medan.

Husnan, S., \& Pudjiastuti, E. (2015). Dasar-Dasar Manajemen Keuangan, Edisi Ketujuh. UPP STIM YKPN. Yogyakart.

Inastri, M. A., \& Mimba, N. P. S. H. (2017). Pengaruh Penerapan Good Corporate Governance dan Pengungkapan Corporate Social Responsibility Pada Nilai Perusahaan. E-Jurnal Akuntansi, 21(2), 1400-1429. https:// doi.org/10.24843/EJA.2017.v21.i02.p20

Jensen, M. C., \& Meckling, W. H. (1976). Theory of the Firm: Managerial Behavior, Agency Costs And Ownership Structure. Journal of Financial Economics, 3(4), 305-360. https://doi.org/http://dx.doi.org/10.1016/0304-405X(76)90026-X

Julianti, D. K. (2015). Pengaruh Mekanisme Good Corporate Governance Terhadap Nilai Perusahaan Dengan Profitabilitas Sebagai Variabel Intervening Pada Perusahaan Manufaktur Yang Terdaftar Di Bursa Efek Indonesia Tahun 2010-2013. Under Graduates thesis, Universitas Negeri Semarang.

Kusumawati, E., \& Setiawan, A. (2019). The Effect Of Managerial Ownership, Institutional Ownership, Company Growth, Liquidity, And Profitability On Company Value. Riset Akuntansi Dan Keuangan Indonesia, 4(2), 136-146. https:// doi.org/10.23917/reaksi.v4i2.8574

Mardiana, I. A., \& Wuryani, E. (2019). Pengaruh Kinerja Lingkungan terhadap Nilai Perusahaan dengan Profitabilitas sebagai Variabel Pemoderasi. Akuntabilitas, 8(1), 1-8.

Mardianto, M., \& Tiono, C. (2019). Analisis Pengaruh Fraud Triangle Dalam Mendeteksi Kecurangan Laporan Keuangan. Jurnal Benefita, 1(1), 41. https:// doi.org/10.22216/jbe.v1i1.3349

Nugrahitha, I. M. A., \& Suprasto, H. B. (2018). Pengaruh Profitabilitas, Leverage, Corporate Governance, dan Karakter Eksekutif pada Tax Avoidance. E-Jurnal Akuntansi, 22(3), 2016-2039. https:/ / doi.org/10.24843/EJA.2018.v22.i03.p14

Pinar, M., \& Guluzar, G. (2010). Ownership Concentration, Managerial Ownership and Firm Performance: Evidence from Turkey. South East European Journal of Economics and Business, 5(1), 57-66.

Prasetyorini, B. F. (2013). Pengaruh Ukuran Perusahaan, Leverage, Price Earning Ratio dan Profitabilitas terhadap Nilai Perusahaan. Jurnal Ilmu Manajemen (JIM), 1(1).

Putranto, P., \& Kurniawan, E. (2018). Effect of Managerial Ownership and Profitability in Firm Value (Empirical Study on Food and Beverage Industrial Sector Company 2012 to 2015). European Journal of Business and Management, 10(25), 96-104.

Saputra, I. P. A., \& Mahyuni, L. P. (2018). Pengaruh Struktur Kepemilikan dan Kinerja Lingkungan Terhadap Nilai Perusahaan. Jurnal Manajemen Dan Bisnis, 15(3), 64-81.

Sari, P., \& Abundanti, N. (2014). Pengaruh Pertumbuhan Perusahaan Dan 
Leverage Terhadap Profitabilitas Dan Nilai Perusahaan. E-Jurnal Manajemen Universitas Udayana, 3(5), 1427-1441.

Setiawanta, Y., \& Hakim, M. A. (2019). Apakah sinyal kinerja keuangan masih terkonfirmasi? : Studi empiris lembaga keuangan di PT. BEI. Jurnal Ekonomi Dan Bisnis, 22(2), 289-312. https:/ / doi.org/10.24914/jeb.v22i2.2048

Sudana, I. M. (2011). Manajemen Keuangan Perusahaan Teori \& Praktik.

Sueb, M. (2001). Pengaruh Biaya Sosial Terhadap Kinerja Keuangan Perusahaan Terbuka di Indonesia. SIMPOSIUM Nasional Akuntansi IV, 167-174.

Sugiyono. (2017). Metode Penelitian Bisnis. CV. Alfabeta.

Suparmini, N. K., Ariyanto, D., \& Wistawan, I. M. A. P. (2020). Pengujian Fraud Diamond Theory Pada Indikasi Financial Statement Fraud Di Indonesia. EJurnal Akuntansi, 30(6), 1441-1457. https://doi.org/10.24843/EJA.2020.v30.i06.p08

Sutama, D. R., \& Lisa, E. (2018). Pengaruh Leverage Dan Profitabilitas Terhadap Nilai Perusahaan (Studi pada Perusahaan Sektor Manufaktur Food and Beverage yang terdaftar di Bursa Efek Indonesia). Jurnal Sains Manajemen $\mathcal{E}$ Akuntansi, X(1), 21-39.

Tjahjono, M. S. (2013). Pengaruh kinerja lingkungan terhadap nilai perusahaan dan kinerja keuangan. Jurnal Ekonomi Universitas Esa Unggul, 4(1), 38-46.

Utama, S. M. (2016). Buku Ajar Aplikasi Analisis Kuantitatif. Denpasar: Fakultas Ekonomi Universitas Udayana.

Wiagustini, N. L. P. (2014). Dasar-dasar Manajemen Keuangan. Denpasar: Udayana University Press.

Wirawati, N. G. P., Putri, I. G. A. M. A. D., \& Badera, I. D. N. (2020). Pengaruh Ukuran Perusahaan, Leverage, Pengungkapan Lingkungan, dan Kinerja Lingkungan pada Nilai Perusahaan. E-Jurnal Akuntansi, 30(9), 2417-2427. https://doi.org/10.24843/eja.2020.v30.i09.p19 